\title{
Ketepatan Waktu Pelayanan Skrining Hipotiroidism Kongenital di Yogyakarta
}

Rini Anggraini, ${ }^{*}$ Suryono Yudha Patria, ${ }^{* *}$ Madarina Julia ${ }^{*}$

"Magister Ilmu Kesehatan Masyarakat, " Departemen Ilmu Kesehatan Anak Fakultas Kedokteran UGM/ RSUP Sardjito,Yogyakarta

Latar belakang. Deteksi dan pengobatan dini hipotiroid kongenital dapat mengurangi risiko terjadinya disabilitas intelektual, sehingga ketepatan waktu pelayanan merupakan kunci keberhasilan program skrining hipotiroid kongenital (SHK) pada bayi baru lahir. Tujuan. Mengevaluasi pelaksanaan program SHK pada bayi baru lahir di Yogyakarta tahun 2013-2015.

Metode. Data ketepatan waktu pengambilan, pengiriman spesimen ke laboratorium dan data umpan balik hasil skrining dikumpulkan melalui catatan dan pelaporan program di fasilitas pelayanan kesehatan, Dinas Kesehatan Provinsi DIY dan Laboratorium Patologi Klinik FK UGM.

Hasil. Persentase pengambilan spesimen yang tidak tepat waktu pada kelompok dana pemerintah (25\%-32\%) lebih besar daripada kelompok dana mandiri (11\%-15\%). Persentase pengiriman spesimen ke laboratorium yang tidak tepat waktu dari kelompok dana pemerintah (38\%-45\%) lebih besar daripada kelompok dana mandiri (7\%-11\%). Hasil tes TSH tinggi diterima oleh Dinas Kesehatan Provinsi DIY/Patologi Klinik UGM ketika usia bayi sudah lebih dari 2 minggu, sedangkan hasil tes yang tidak terbaca diterima ketika usia bayi 22-59 hari.

Kesimpulan. Setelah dilaksanakan hampir 10 tahun, cakupan program skrining hipotiroid kongenital di Yogyakarta baru mencapai $10 \%$ bayi baru lahir. Masih banyak terjadi ketidaktepatan waktu pelayanan. Alur jejaring kerjasama program juga kurang efisien. Sari Pediatri 2017;18(6):436-42

Kata kunci: evaluasi program, hipotiroid kongenital, skrining bayi baru lahir

\section{Timeliness of Screening for Congenital Hypothyroidism in Yogyakarta}

Rini Anggraini, ${ }^{*}$ Suryono Yudha Patria, ${ }^{* *}$ Madarina Julia*

Background. Early detection and management of congenital hypothyroidism will minimize risk for intellectual disability. Hence, timing is the key success for its screening in newborns.

Objective. The study aimed to evaluate the implementation of newborn screening for congenital hypothyroidism in Yogyakarta year 2013-2015.

Methods. Data on timeliness of blood sampling, sample delivery and delivery of results from the assigned laboratory were collected from records and reports of the health service facilities, Provincial Health Office and Clinical Pathology Laboratory of the Medical Faculty UGM.

Result. The percentage of not-timely collected specimens was higher in the government fund group (25\%-32\%) vs. the private fund group (11\%-15\%). The percentage of specimens not-timely delivered to the assigned laboratory was higher in the private fund group (38\%-45\%) vs. government fund group (7\%-11\%). High TSH test results were received by Provincial Health Office/ Clinical Pathology Laboratory when the babies were more than 2 weeks old. Some tests were identified to be unreadable when babies were already between 22-59 days old.

Conclusion. After 10 years implementation, the coverage of the newborn screening is $10 \%$. The results of the screening were, mostly, not-timely received. The system was not efficient. Sari Pediatri 2017;18(6):436-42

Keywords: program evaluation, newborn screening, congenital hypothyroidism

Alamat korespondensi: Prof. Dr. Madarina Julia, SpA(K). Departemen Ilmu Kesehatan Anak, Fakultas Kedokteran UGM/ RSUP Sardjito. Yogyakarta. Jl. Kesehatan, Sekip, Yogyakarta 55281. Email: madarinajulia@ugm.ac.id; madarinajulia@yahoo.com 
$\mathrm{H}$ ipotiroid kongenital (HK) merupakan keadaan kekurangan hormon tiroid sejak bayi baru lahir. ${ }^{1,2}$ Secara global, prevalensi HK diperkirakan mendekati 1:3000 kelahiran, sedangkan di Indonesia diperkirakan sekitar 1: 2513 kelahiran. ${ }^{3}$ Gejala HK pada awal kehidupan sangat samar dan tidak khas, sementara keterlambatan pengobatan pada bayi kasus HK akan mengakibatkan gangguan pertumbuhan fisik dan keterbelakangan mental yang permanen. ${ }^{1,2,4}$ Oleh karena itu, deteksi dini pada semua bayi baru lahir dan pemberian terapi sulih hormon tiroid sesegera mungkin menjadi sangat penting. ${ }^{25,6}$ Terapi pada bayi HK yang dimulai pada umur kurang dari dua minggu akan memberikan hasil terbaik untuk intelegensi anak. ${ }^{2,7}$

Program Skrining Hipotiroid Kongenital (SHK) di Provinsi D.I. Yogyakarta telah dimulai sejak tahun 2006, tetapi hanya sekitar $10 \%$ dari total 43.704 jiwa bayi baru lahir pada tahun 2015 yang diikutsertakan program SHK. Program SHK masih perlu berkembang secara berkesinambungan hingga dapat memberikan dampak lebih besar bagi pembangunan bangsa. Ketepatan waktu pelayanan juga merupakan kunci keberhasilan program $\mathrm{SHK}^{8}$ sehingga sudah seharusnya pelaporan hasil tes $\mathrm{SHK}$ bisa disampaikan tepat waktu pada pasien.

Berbagai masalah dapat timbul dalam pelaksanaan SHK baik pada alur jejaring kerjasama, manajemen data, dana operasional dan respon masyarakat sehingga perlu dilakukan evaluasi terhadap pelaksanaan program SHK di D.I. Yogyakarta (DIY). Penelitian ini lebih difokuskan pada sisi provider (pemberi pelayanan kesehatan) karena hakikatnya sistem pelayanan yang baik akan meningkatkan keikutsertaan masyarakat dalam program. Penelitian bertujuan untuk menganalisis kendala dan masalah dalam pelaksanaan SHK yang berfokus pada ketepatan waktu pelayanan.

\section{Metode}

Studi evaluasi deskriptif dengan metode retrospektif dilaksanakan pada bulan Februari-April 2016. Sampel penelitian adalah seluruh bayi baru lahir yang ikut program SHK di Fasilitas Pelayanan Kesehatan (Fasyankes) wilayah kerja Dinas Kesehatan (Dinkes) Provinsi D.I. Yogyakarta tahun 2013-2015 serta memiliki data yang tercatat dan lengkap. Fasyankes pelaksana SHK di Provinsi DIY terdiri dari 5 rumah sakit umum daerah (RSUD), 7 Puskesmas, dan 3 Rumah Sakit Swasta. Spesimen SHK yang diambil dari bayi baru lahir di RSUD dan Puskesmas dikategorikan dalam kelompok dana pemerintah, sedangkan spesimen yang diambil dari RS Swasta dikategorikan dalam kelompok dana mandiri. Data terkait sumber input program SHK, yaitu tenaga terlatih, dana dan sarana, serta penjelasan terkait data ketepatan waktu pelayanan yang diteliti diperoleh dari informasi yang diberikan tenaga kesehatan pelaksana program serta telaah dokumen dan observasi ke fasyankes.

Data yang diambil, yaitu ketepatan waktu pengambilan dan pengiriman spesimen serta pelaporan hasil tes SHK dikumpulkan melalui telaah dokumen, penggabungan dan pengolahan data pelaporan program. Sumber data tersebut, yaitu data pelaporan hasil pemeriksaan laboratorium yang diperoleh dari Departemen Patologi Klinik FK UGM (PK FK UGM) dan Dinas Kesehatan (Dinkes) Provinsi DIY, data catatan/registrasi pasien dari tiap Fasyankes pelaksana program, serta data tanggal hasil tes SHK diterima Dinkes Provinsi DIY/PK FK UGM dengan mengecek tanggal email data dikirimkan. Data dianalisis secara deskriptif dan disajikan dalam bentuk persentase dan ukuran pemusatan (rerata, median, dan nilai kuartil).

\section{Hasil}

Program SHK di Provinsi DIY telah berjalan sejak tahun 2006. Terdapat 15 fasyankes yang melaksanakan program ini hingga akhir tahun 2015 dengan rincian 7 Puskesmas rawat inap dari total 42 Puskesmas rawat inap atau 121 Puskesmas di Provinsi DIY, 5 RSUD dari total 7 RS umum pemerintah dan 3 RS TNI/POLRI, serta 3 RS swasta dari 35 RS swasta dan 8 Rumah Sakit Ibu dan Anak (RSIA). Salah satu Puskesmas telah berhenti mengirimkan spesimen sejak awal tahun 2015. Jika cakupan fasyankes yang melaksanakan program SHK dibandingkan berdasarkan jenisnya, program SHK baru dilaksanakan di 7 (5,8\%) Puskesmas dan 8 $(15,1 \%)$ RS dari total 121 Puskesmas dan 53 RS yang ada di wilayah Provinsi DIY.

Faktor input seperti dana, sarana, dan tenaga terlatih juga menjadi faktor penting dalam keberhasilan suatu program. Berdasarkan hasil penelitian, pada setiap fasyankes pelaksana program SHK, setidaknya ada seorang yang pernah sekali atau beberapa kali ikut pelatihan dan atau rapat evaluasi/sosialisasi 
Rini Anggraini dkk: Ketepatan waktu pelayanan skrining hipotiroidism kongenital di Yogyakarta

DANA PEMERINTAH

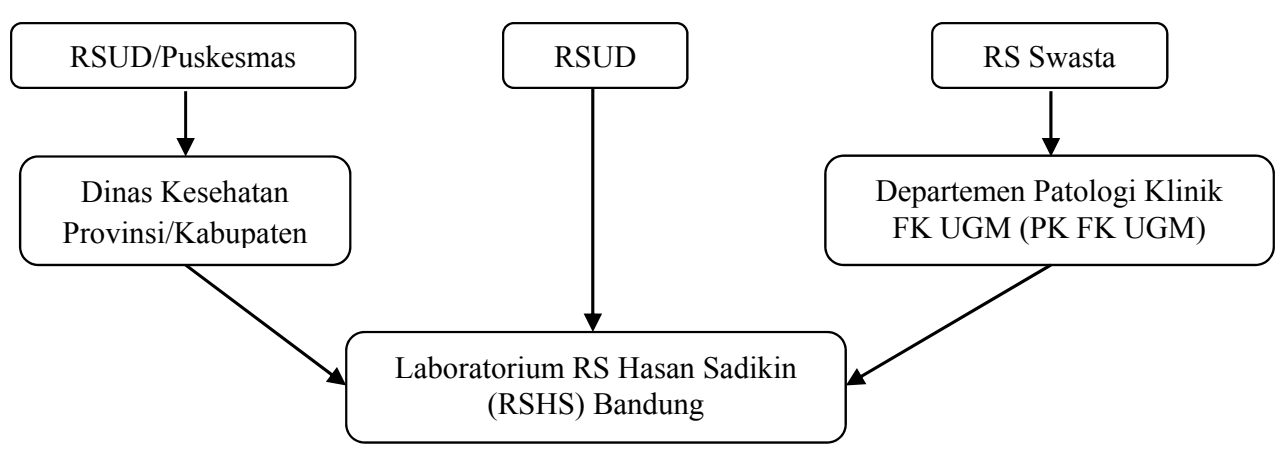

Gambar 1. Alur Pengiriman Spesimen SHK Provinsi DIY Tahun 2013-2015

Tabel 1. Ketepatan waktu pengambilan spesimen tahun 2013-2015

\begin{tabular}{lcccccccc}
\hline & \multicolumn{9}{c}{ Sumber dana } \\
\cline { 2 - 8 } Tahun & \multicolumn{9}{c}{ Pemerintah } & \multicolumn{3}{c}{ Mandiri } \\
\cline { 2 - 8 } & $\mathrm{N}$ & $\begin{array}{c}\text { Tepat waktu } \\
\mathrm{n}(\%)\end{array}$ & $\begin{array}{c}\text { Terlalu dini } \\
\mathrm{n}(\%)\end{array}$ & $\begin{array}{c}\text { Terlambat } \\
\mathrm{n}(\%)\end{array}$ & $\mathrm{N}$ & $\begin{array}{c}\text { Tepat waktu } \\
\mathrm{n}(\%)\end{array}$ & $\begin{array}{c}\text { Terlalu dini } \\
\mathrm{n}(\%)\end{array}$ & $\begin{array}{c}\text { Terlambat } \\
\mathrm{n}(\%)\end{array}$ \\
\hline 2013 & 3393 & $2293(67,6)$ & $339(9,9)$ & $761(22,4)$ & 1.354 & $1202(88,8)$ & $44(3,2)$ & $108(7,9)$ \\
2014 & 2714 & $2028(74,7)$ & $40(1,5)$ & $646(23,8)$ & 1.300 & $1117(85,9)$ & $20(1,5)$ & $163(12,5)$ \\
2015 & 2215 & $1589(71,7)$ & $29(1,3)$ & $597(26,9)$ & 936 & $792(84,6)$ & $6(0,6)$ & $138(14,7)$ \\
\hline
\end{tabular}

Catatan:

- $\quad$ Tepat waktu : jika usia pada saat spesimen diambil $>1$ hari dan sampai usia 3 hari

- Terlalu dini : jika usia pada saat spesimen diambil $<1$ hari

- Terlambat : jika usia pada saat spesimen diambil $\geq 4$ hari

terkait program SHK. Beberapa tenaga kesehatan masih kesulitan mengambil spesimen dari tumit bayi. Sekitar 10\% (dana pemerintah dan mandiri) dari total kelahiran setiap tahunnya di Provinsi DIY telah mengikuti program SHK. Rincian jumlah bayi baru lahir di Provinsi DIY yang terdata mengikuti SHK, baik dari dana pemerintah dan mandiri, pada tahun 2013, 2014, dan 2015 berturut-turut 4942 (10,8\%) dari total kelahiran 45.436 jiwa, $4567(10,0 \%)$ dari total kelahiran 45.592 jiwa, dan 4512 jiwa (10,3\%) dari total kelahiran 43.704 jiwa.

\section{Ketepatan waktu pengambilan spesimen}

Hasil penelitian menunjukkan bahwa usia pasien saat spesimen diambil untuk periode tahun 2013-2015 fluktuatif dari tahun ke tahun. Pada kelompok dana pemerintah, sebagian besar spesimen diambil ketika pasien berusia 2-4 hari. Pada kelompok dana mandiri, sebagian besar spesimen diambil ketika pasien berusia
2-5 hari. Pengambilan spesimen darah yang paling ideal menurut Permenkes No.78 Tahun 2014 adalah ketika usia bayi 48 sampai 72 jam dan masih bisa ditoleransi bila diambil pada usia antara 24-48 jam. Data yang lengkap dikategorikan menjadi tepat waktu, terlalu dini dan terlambat, tanpa memperhatikan kondisi khusus bayi seperti prematur, berat lahir rendah, dalam masa perawatan NICU (Neonatal Intensive Care Unit), dan lainnya (Tabel 1).

\section{Ketepatan waktu pengiriman spesimen}

Hasil penelitian menunjukkan bahwa sebagian besar kelompok dana pemerintah mengirimkan spesimen ke Laboratorium RS Hasan Sadikin (RSHS) Bandung pada saat usia pasien masih lebih muda, yaitu antara usia 5-7 hari dibandingkan dengan kelompok dana mandiri yang mengirimkan spesimen ketika pasien sudah berusia antara 10-13 hari. Proses pengiriman spesimen SHK ke laboratorium RSHS tersebut 
dilakukan melalui beberapa jalur (Gambar 1).

Pengiriman spesimen yang paling ideal menurut Permenkes No.78 Tahun 2014 adalah tidak lebih dari 7 hari sejak spesimen diambil dan lama perjalanan pengiriman tidak lebih dari 3 hari. Tabel 2 menyajikan data lengkap yang dikategorikan tepat waktu dan terlambat tanpa memperhatikan lama perjalanan pengiriman. Berdasarkan informasi dari tenaga kesehatan pelaksana program diketahui bahwa spesimen dikirim dengan jasa pengiriman kilat 1 hari.

\section{Ketepatan waktu pelaporan hasil tes}

Hasil tes skrining dari laboratorium RSHS berupa rekapan file data excel diterima Dinkes Provinsi DIY/ PK FK UGM melalui surat elektronik dalam beberapa periode pada setiap tahunnya, sedangkan hasil tes dengan kadar TSH tinggi disampaikan langsung ketika hasil keluar melalui telepon/SMS. Hasil pemeriksaan spesimen kelompok dana mandiri dari Laboratorium RSHS dikirimkan ke PK FK UGM dan diteruskan ke RS Swasta pelaksana SHK, sedangkan hasil dari spesimen kelompok dana pemerintah dikirimkan ke Dinkes Provinsi dan diteruskan ke Dinkes Kabupaten/ RSUD/Puskesmas. Tabel 3 menyajikan data usia pasien saat hasil tes diterima Dinkes Provinsi DIY/PK FK UGM.

Pada periode tahun 2013-2015 selalu ada spesimen yang dilaporkan tidak terbaca/tidak dapat diperiksa di Laboratorium RSHS dengan rincian persentase jumlahnya berturut-turut yaitu 1,3\%, 2,9\%, dan 1,2\% dari total spesimen yang diperiksa. Hasil pemeriksaan dengan kesimpulan spesimen tidak terbaca sebagian besar diterima Dinkes Provinsi DIY/PK FK UGM saat pasien berusia antara 22 hari sampai dengan 59 hari.

Selama periode tahun 2013-2015, hasil pemeriksa-

Tabel 2. Ketepatan waktu pengiriman spesimen tahun 2013-2015

\begin{tabular}{|c|c|c|c|c|c|c|}
\hline \multirow{3}{*}{ Tahun } & \multicolumn{6}{|c|}{ Sumber dana } \\
\hline & \multicolumn{3}{|c|}{ Pemerintah } & \multicolumn{3}{|c|}{ Mandiri } \\
\hline & $\mathrm{N}$ & $\begin{array}{c}\text { Tepat waktu } \\
\mathrm{n}(\%)\end{array}$ & $\begin{array}{c}\text { Terlambat } \\
\mathrm{n}(\%)\end{array}$ & $\mathrm{N}$ & $\begin{array}{c}\text { Tepat waktu } \\
\mathrm{n}(\%)\end{array}$ & $\begin{array}{c}\text { Terlambat } \\
\mathrm{n}(\%)\end{array}$ \\
\hline 2013 & 1.347 & $1.248(92,7)$ & $99(7,3)$ & 1.366 & $849(62,2)$ & $517(37,8)$ \\
\hline 2014 & 1.003 & $925(92,2)$ & $78(7,8)$ & 1.238 & $683(55,2)$ & $555(44,8)$ \\
\hline 2015 & 1.893 & $1.685(89,0)$ & $208(10,9)$ & 218 & $125(57,3)$ & $93(42,7)$ \\
\hline
\end{tabular}

Catatan:

- $\quad$ Tepat waktu : jika usia pada saat spesimen dikirim $\leq 10$ hari

- Terlambat : jika usia pada saat spesimen dikirim $>10$ hari

Tabel 3. Median usia pasien saat hasil tes SHK diterima Dinkes Provinsi DIY/PK FK UGM

\begin{tabular}{|c|c|c|c|c|c|}
\hline \multirow{3}{*}{ Tahun } & \multirow{3}{*}{$\begin{array}{c}\text { Hasil pemeriksaan } \\
\text { laboratorium }\end{array}$} & \multicolumn{4}{|c|}{ Sumber dana } \\
\hline & & \multicolumn{2}{|r|}{ Pemerintah } & \multicolumn{2}{|r|}{ Mandiri } \\
\hline & & $\mathrm{n}(\%)$ & Median (Q1-Q3) usia (hari) & $\mathrm{n}(\%)$ & Median (Q1-Q3) usia (hari) \\
\hline \multirow[t]{4}{*}{2013} & TSH normal & $3455(98,2)$ & $20(16-25)$ & $1383(99,5)$ & $25(21-29)$ \\
\hline & TSH tinggi & $1(0,02)$ & - & $2(0,1)$ & - \\
\hline & Tidak terbaca & $61(1,7)$ & $20(15-29)$ & $4(0,2)$ & $34(33-35)$ \\
\hline & Total & $3517(100)$ & & $1389(100)$ & \\
\hline \multirow[t]{4}{*}{2014} & TSH normal & $2888(95,6)$ & $20(15-28)$ & $1378(99,4)$ & $28(24-35)$ \\
\hline & TSH tinggi & $4(0,1)$ & $13(11-14)$ & $6(0,4)$ & - \\
\hline & Tidak terbaca & $128(4,2)$ & $19(13-29)$ & $2(0,1)$ & $23(21-25)$ \\
\hline & Total & $3020(100)$ & & $1386(100)$ & \\
\hline \multirow[t]{4}{*}{2015} & TSH normal & $2424(98,1)$ & $40(24-62)$ & $1019(99,7)$ & $36(26-50)$ \\
\hline & TSH tinggi & $3(0,1)$ & $12(12-14)$ & $3(0,2)$ & $17(16-23)$ \\
\hline & Tidak terbaca & $43(1,7)$ & $53(31-81)$ & 0 & - \\
\hline & Total & $2470(100)$ & & $1022(100)$ & \\
\hline
\end{tabular}


Rini Anggraini dkk: Ketepatan waktu pelayanan skrining hipotiroidism kongenital di Yogyakarta

Tabel 4. Usia suspect hipotiroid kongenital ketika tes ulang tahun 2013-2015

\begin{tabular}{|c|c|c|c|c|c|c|c|}
\hline \multirow[t]{2}{*}{ No. } & \multirow[t]{2}{*}{ Inisial } & \multirow[t]{2}{*}{ Tahun } & \multirow[t]{2}{*}{ Sumber dana } & \multicolumn{4}{|c|}{ Usia pasien (hari) } \\
\hline & & & & $\begin{array}{l}\text { Spesimen } \\
\text { diambil }\end{array}$ & $\begin{array}{l}\text { Spesimen } \\
\text { dikirim }\end{array}$ & $\begin{array}{l}\text { Hasil diterima PK FK } \\
\text { UGM/Dinkes Provinsi }\end{array}$ & Tes ulang \\
\hline 1. & YJ & 2013 & Pemerintah & 2 & 3 & 11 & - \\
\hline 2. & RDF & 2013 & Mandiri & 1 & 9 & - & 33 \\
\hline 3. & $\mathrm{RD}$ & 2013 & Mandiri & 1 & 12 & - & 31 \\
\hline 4. & TP & 2014 & Pemerintah & 1 & 7 & 15 & - \\
\hline 5. & MK & 2014 & Pemerintah & 0 & - & 5 & - \\
\hline 6. & AF1 & 2014 & Pemerintah & 3 & 9 & 13 & 20 \\
\hline 7. & $\mathrm{AF} 2$ & 2014 & Pemerintah & 3 & 9 & 13 & 20 \\
\hline 8. & FF & 2014 & Mandiri & - & 13 & - & 34 \\
\hline 9. & WT & 2014 & Mandiri & 2 & 10 & - & 31 \\
\hline 10. & $\mathrm{AD}$ & 2014 & Mandiri & 2 & 3 & - & 22 \\
\hline 11. & $\mathrm{MN}$ & 2014 & Mandiri & 3 & 9 & - & - \\
\hline 12. & WS & 2014 & Mandiri & 2 & 3 & - & - \\
\hline 13. & MTD & 2014 & Mandiri & 2 & - & 13 & - \\
\hline 14. & SM & 2015 & Pemerintah & 0 & - & 16 & 19 \\
\hline 15. & EP & 2015 & Pemerintah & 3 & 4 & 12 & 18 \\
\hline 16. & IJ & 2015 & Pemerintah & 3 & 5 & 12 & 23 \\
\hline 17. & PS & 2015 & Mandiri & - & 7 & 15 & 20 \\
\hline 18. & AA & 2015 & Mandiri & 5 & - & 28 & 34 \\
\hline 19. & ES & 2015 & Mandiri & - & - & 17 & - \\
\hline
\end{tabular}

an yang menunjukkan kadar TSH tinggi dari kelompok dana pemerintah diterima Dinkes Provinsi DIY ketika usia pasien dalam rentang waktu antara 11 hari dan 16 hari dengan hanya satu orang pasien yang hasil tesnya disampaikan ketika usia pasien 5 hari, sedangkan hasil tinggi dari kelompok dana mandiri diterima PK FK UGM ketika usia pasien dalam rentang waktu antara 13 hari dan 28 hari tertera pada Tabel 4.

\section{Pembahasan}

Program SHK di Provinsi DIY telah berjalan hampir sekitar sepuluh tahun jika dihitung sejak program pendahuluan yang dimulai pada tahun 2006. Namun, hingga awal tahun 2016, cakupan fasyankes yang menjalankan program ini masih sangat rendah $(8,6 \%)$ dari total 174 fasyankes (RS dan Puskesmas) yang ada di wilayah Provinsi DIY. Cakupan Fasyankes pelaksana SHK yang rendah juga diikuti dengan cakupan program. Alokasi dana pemerintah untuk program SHK hingga tahun 2015 masih terbatas dari APBN
(Anggaran Pendapatan dan Belanja Negara) saja yang hanya dapat mencakup sekitar 3000 - 3500 bayi baru lahir per tahunnya. Keterbatasan dana yang diberikan pemerintah menyebabkan keikutsertaan fasyankes swasta menjadi penting dalam perkembangan program SHK. Namun pada kenyataannya, sektor swasta hanya dapat mencakup sekitar 1000 - 1400 bayi baru lahir yang ikut SHK per tahunnya.

Prosedur pencairan dana pemerintah untuk SHK cukup menghabiskan waktu sehingga ada masa vakum pelaksanaan SHK pada kelompok dana pemerintah. Program SHK pada sektor pemerintah dapat terhenti beberapa bulan setiap tahunnya karena sarana penting, seperti kertas saring dan lancet tidak tersedia. Dukungan penuh pemerintah dengan program lain yang terintegrasi seperti imunisasi bayi baru lahir mungkin dapat mendukung ketersediaan logistik skrining. ${ }^{8,9}$

Pada setiap fasyankes pelaksana program SHK, paling tidak ada satu orang yang pernah sekali atau beberapa kali ikut pelatihan (praktek dengan phantom) dan atau sosialisasi terkait cara pengambilan spesimen SHK. Namun, beberapa tenaga kesehatan terkadang mengalami kegagalan memenuhi bulatan kertas 
saring dengan spesimen darah. Sistem pelaksanaan di Fasyankes yang mengharuskan adanya rotasi kerja juga mengakibatkan tenaga kesehatan mempelajari teknik pengambilan spesimen dari panduan saja karena rekan kerjanya yang sudah mengikuti pelatihan tidak diketahui keberadaannya. Selain sistem kerja yang lebih baik, implementasi program skrining bayi baru lahir membutuhkan pelatihan teknis atau pendampingan praktek oleh tenaga ahli yang akan membantu peningkatan keterampilan tenaga kesehatan. ${ }^{9}$

Spesimen diambil ketika rata-rata usia antara 2-5 hari. Median waktu pengambilan spesimen selama periode 2013-2015 mayoritas 2 hari, sama seperti pencapaian program SHK di Alberta, Kanada, tahun 2005-2008. ${ }^{10}$ Ketentuan pihak BPJS untuk dapat pulang segera pasca melahirkan mengakibatkan persentase spesimen yang diambil terlalu dini pada kelompok dana pemerintah lebih besar dibandingkan kelompok dana mandiri. Spesimen kelompok dana pemerintah yang lebih banyak diambil dari bagian NICU menyebabkan persentase spesimen yang diambil terlambat juga lebih besar pada kelompok dana pemerintah. Selain itu, menurut Basu dkk ${ }^{11}$ pelayanan kesehatan sektor swasta cenderung lebih sering memberikan keramahtamahan dan pelayanan yang tepat waktu dibandingkan sektor publik.

Persentase spesimen yang dikirim terlambat jauh lebih besar pada kelompok dana mandiri (38\%-45\%) dibandingkan kelompok dana pemerintah (7\%-11\%). Hal tersebut karena spesimen dari kelompok dana mandiri dikumpulkan dan didata terlebih dahulu di PK FK UGM sebelum dikirim ke laboratorium RSHS, sedangkan spesimen kelompok dana pemerintah langsung dikirimkan pihak Fasyankes atau dinkes ketika diambil tanpa didata lagi. Pengumpulan dan pendataan di PK FK UGM membuat data spesimen yang dikirimkan dan hasil yang didapatkan pihak Fasyankes menjadi terperinci dan terkoordinasi dengan lebih baik, namun juga menyebabkan penundaan waktu kirim. Batalden and Davidoff ${ }^{12}$ memaparkan bahwa sistem pelaksanaan yang baik akan meningkatkan kualitas pelayanan Fasyankes.

Menurut Permenkes No.78 Tahun 2014 hasil yang dianggap normal akan disampaikan kepada pengirim spesimen dalam waktu 7 hari, namun ternyata hasil tes SHK yang normal disampaikan ketika rata-rata usia pasien di atas 20 hari dan bahkan pada tahun 2015 ketika rata-rata usia pasien di atas 1 bulan. Informasi mengenai spesimen yang tidak dapat diperiksa/terbaca diterima Dinkes Provinsi DIY dan PK FK UGM saat bayi sudah berusia 22 hari sampai dengan 59 hari. Keterlambatan informasi ini juga menjadi masalah karena bisa jadi ada penderita hipotiroid kongenital di antara bayi-bayi tersebut. Penyampaian hasil TSH tinggi memang telah baik karena hasil sesegera mungkin disampaikan, yaitu sekitar 11-28 hari, tetapi waktu ini telah lewat dari saat usia terbaik penderita $\mathrm{HK}$ untuk diberikan terapi sulih hormon. ${ }^{2,10}$ Kolaborasi yang kuat antara semua pihak terkait dan jaringan kerja yang efektif sangat penting untuk perkembangan dan keberlangsungan program skrining bayi baru lahir, terutama dalam memberikan pelayanan yang tepat waktu. Selain itu, administrasi program yang bagus akan menjamin keberhasilan program. ${ }^{8,13}$

Hasil tes yang terlambat diketahui mengakibatkan pasien suspect HK juga terlambat mengikuti tes konfirmasi yaitu sekitar di atas usia 18 hari, bahkan di atas 1 bulan. Masyarakat yang awam tentang SHK juga dapat menjadi alasan tes konfirmasi yang terlambat sebagaimana menurut Dilli dkk ${ }^{14}$ bahwa rakyat Turki yang tidak datang untuk mengikuti tes kedua program SHK karena kepercayaan kuno, alasan sosial ekonomi, dan kesulitan dalam komunikasi/transportasi. Penyampaian hasil tes yang tepat waktu merupakan hak pasien sebagaimana pernyataan pasal 8 Undangundang nomor 36 Tahun 2009 tentang Kesehatan. Pelayanan yang tepat waktu akan meningkatkan kualitas pelayanan kesehatan dan berdampak positif bagi perkembangan program. ${ }^{15,16}$

Kunci keberhasilan program SHK adalah ketepatan waktu, ${ }^{9}$ tetapi dalam pelaksanaan program SHK di Provinsi DIY masih banyak keterlambatan waktu pelayanan, terutama pada penyampaian hasil pemeriksaan laboratorium yang sangat berdampak pada ketepatan waktu tindak lanjut. Keterlambatan tersebut bisa terjadi karena kurang efisiennya alur pengiriman yang bertingkat pada kelompok dana mandiri dan alur jejaring kerjasama yang mengharuskan pemeriksaan di Laboratorium RSHS Bandung.

Penyampaian hasil pemeriksaan spesimen SHK baik dengan dana pemerintah maupun mandiri tidak akan membutuhkan waktu yang lama jika pemeriksaan dilakukan di laboratorium setempat yang telah mampu melakukan pemeriksaan spesimen SHK. Tindak lanjut atas hasil pemeriksaan laboratorium SHK juga dapat segera dilakukan dan pendataan peserta SHK baik dengan hasil tes kadar TSH tinggi, tidak terbaca maupun normal akan lebih cepat. 


\section{Kesimpulan dan Saran}

Setelah berjalan hampir 10 tahun, cakupan bayi yang menjalani skrining hipotiroid kongenital di Provinsi DIY masih sangat rendah, sekitar 10\%. Ketepatan waktu diagnosis hipotiroid kongenital juga masih sangat terlambat. Alur jejaring kerjasama program SHK yang kurang efisien mengakibatkan keterlambatan waktu pelayanan, terutama pada waktu penyampaian dan tindak lanjut hasil tes SHK. Meningkatkan keterlibatan fasyankes dan kinerja tenaga kesehatan di Fasyankes pelaksana SHK serta membentuk alur jejaring kerjasama yang lebih pendek dengan melakukan pemeriksaan spesimen di laboratorium lokal akan sangat membantu untuk memberikan pelayanan yang tepat waktu.

\section{Daftar pustaka}

1. Direktorat Jenderal Bina Gizi dan Kesehatan Ibu dan Anak Kementerian Kesehatan RI. Pedoman skrining hipotiroid kongenital. Jakarta: Kementerian Kesehatan RI; 2012.

2. Rose SR, Brown RS. Update of newborn screening and therapy for congenital hypothyroidism. Pediatrics 2006; 117:2290-303.

3. Pusat Data dan Informasi Kementerian Kesehatan RI. Situasi dan Analisis Penyakit Tiroid. International Thyroid Awareness Week; 25-31 Mei 2015: Kementerian Kesehatan RI; 2015.

4. Behrman RE, Kliegman R, Arvin AM. Nelson: Ilmu Kesehatan Anak Jakarta: EGC. 3. 15 ed2000. h. 1938-43.

5. Wirawan A, Sunartini, Suryawan Bikin, Soetjiningsih. Tumbuh kembang anak hipotiroid kongenital yang diterapi dini dengan levo-tiroksin dan dosis awal tinggi. Sari Pediatri 2013;15:69-74.
6. Shanholtz HJ. Congenital Hypothyroidism. J Pediatr Nurs 2013;2:200-2.

7. Rastogi MV, LaFranchi SH. Congenital hypothyroidism. Orphanet J Rare Dis 2010;5:1-22.

8. Therrell BL, Padilla CD. Barriers to implementing sustainable national newborn screening in developing health systems. Int J Pediatr and Adol Med (IJPAM). 2014;1:49-60.

9. Padilla CD, Krotoski D, Therrell BL. Newborn screening progress in developing countries_overcoming internal barriers. Semin Perinatol 2010;34:145-55.

10. Dawrant JM, Pacaud D, Wade A, Archer S, Bamforth FJ. Informatics of newborn screening for congenital hypothyroidism in Alberta 2005-08: flow of information from birth to treatment. Can J Pub Health 2011;102:64-7.

11. Basu S, Andrews J, Kishore S, Panjabi R, Stuckler D. Comparative performance of private and public healthcare systems in low-and middle-income countries: a systematic review. PLoS med 2012;9:e1001244.

12. Batalden PB, Davidoff F. What is "quality improvement" and how can it transform healthcare? Qual Saf Health Care 2007;16:2-3.

13. Padilla CD, Therrell Jr BL. Consolidating newborn screening efforts in the Asia Pacific region. J Community Genet 2012;3:35-45.

14. Dilli D, Çzbaş S, Acıcan D, Yamak N, Ertek M, Dilmen U. Establishment and development of a national newborn screening programme for congenital hypothyroidism in Turkey. J Clin Res Pediatr Endocrinol 2013;5:73-9.

15. Veillard J, Champagne F, Klazinga N, Kazandjian V, Arah O, Guisset A-L. A performance assessment framework for hospitals: the WHO regional office for Europe PATH project. Int J Qual Health Care 2005;17:487-96.

16. The Scottish Government. The healthcare quality strategy for NHSScotland. Edinburgh: The Scottish Government; 2010. 